\title{
Methodology of work at school tourism clubs in interwar Poland
}

\begin{abstract}
The article concerns the methodology of work in school regional clubs in the Second Republic of Poland. Since 1919, first in Krakow and then in the whole of Poland, school regional clubs have been established, particularly in secondary schools and higher grades of elementary schools. The tourism movement in schools was supported by the educational authorities. The article presents an outline of the ideologies of school regional clubs, the stages of their internal development, the scope of activities and the evaluation of their work made by the organisers, along with recommendations. In Poland, the inter-war tourism movement in schools was part of the school's innovative didactic and educational activities.
\end{abstract}

Keywords: school tourism movement in interwar Poland, school youth tourism clubs, school organisations in interwar Poland, education in Poland in the years 1918-1939

\section{Introduction}

The first school regional clubs were established in mid-1919, initially in Krakow, and later all over Poland in secondary schools and higher grades of elementary schools. ${ }^{1}$ These organisations gained the support of central and local educational authorities. The Ministry of Religious Denominations and Public Education instructed managers and directors of educational institutions to create school tourism clubs, approved their regulations and organised their cooperation with the school authorities. ${ }^{2}$ The students' tourism

\footnotetext{
${ }^{1}$ Organizacja Kół Krajoznawczych Młodzieży Szkolnej, [in:] Koła Krajoznawcze Młodzieży Szkolnej. Idea - Organizacja - Historia - Pieśni, Krakow 1934, Krakow 1934, Nakład Komisji Kół Krajoznawczych Młodzieży Szkolnej Rady Głównej Polskiego Towarzystwa Krajoznawczego, p. 9.

${ }^{2}$ Memorandum of the Ministry of Religious Denominations and Public Education of 22 October 1935 on School Youth Tourist Clubs, Official Journal of the Brzesko School District Board 1936, No. 2; Memorandum of the Ministry of Religious Denominations and Public Education of 8 July 1937 on Tourism Movement, Journal of Laws of the MRDaPE, no. 8.
} 
movement was headed by the Commission of School Youth's Tourism Clubs of the Main Board of the Polish Tourism Association, led by Leopold Węgrzynowicz. ${ }^{3}$ The press organ of the school's tourist clubs was the Orli Lot (Eagle Flight) magazine, published throughout the entire interwar period. ${ }^{4}$ The goal of each of the clubs was:"'a) promotion of tourism among youth, b) training youth for independent tourism work, c) caring for natural monuments and human works. ${ }^{5}$

The tourist movement of schoolchildren and youth aimed to educate them "to become citizens who knew their country and its needs, who were attached to the Polish State and cared about its greatness and power." 6 This was achieved by various means, such as the preparation and organisation of trips, courses, camps, tourism conventions, lectures and discussions, exhibitions and competitions, hostels and the publishing of magazines and books. The Regulations of the School Youth Tourism Clubs, which regulated various aspects of their activities and indicated that the main forms of work of the members of the school's tourist clubs included meetings, lectures and excursions ${ }^{7}$, were developed and approved.

Students' work in school tourism organisations, which comprised getting to know Poland, could not be characterised by randomness, casual nature and lack of planning. It had a systematic agenda aimed at educating young people to become citizens who know, understand and love their homeland ${ }^{8}$. The aim of the article is to present the methodology

${ }^{3}$ Cz. SKOPOWSKI, Rys historii i pracy Kół Krajoznawczych Młodzieży Szkolnej, [in:] Koła Krajoznawcze Młodzieży Szkolnej. Idea - Organizacja - Historia - Pieśni, Krakow 1934, Nakład Komisji Kół Krajoznawczych Młodzieży Szkolnej Rady Głównej Polskiego Towarzystwa Krajoznawczego, Krakow 1934, pp. 17; Cz. SKOPOWSKi, Koła Krajoznawcze Młodzieży Szkolnej, Przyjaciel Szkoły 1933, no. 10, pp. 291. Cf., A. CZARNOWSKI, Leopold Węgrzynowicz, organizator krajoznawstwa wśród młodzieży, Warsaw 1987.

${ }^{4}$ M. KITOWSKA, Orli Lot (1920-1939). Z problematyki turystyczno-krajoznawczej edukacji młodzieży szkolnej, [in]: Młody czytelnik w świecie książk, biblioteki i informacji. K. HESKA-KWAŚNIEWICZ, I. SOCHA (eds.) Katowice 1996, Wydawnictwo Naukowe Uniwersytetu Śląskiego, pp. 69-70.

${ }^{5}$ Koła krajoznawcze młodzieży szkolnej, Official Journal of Lublin KOS, 1930, no. 2, pp. 58-59.

${ }^{6}$ Regulations of the Youth Tourist Clubs, bmw, 1934, pp. 1. Achievement of this objective entailed the need to formulate specific objectives, which included: "a) awakening the love of travelling around the country and developing independence in discovery; b) getting to know human labour workshops, awakening the passion for work and trust in one's own strength; c) learning and assessing the values brought to collective life by particular social strata and ethnic groups; d) getting to know the past of the land and Polish culture; e) collecting tourism materials and cooperation with scientific institutions; f) protection of homeland, historical monuments and nature; g) stimulation of initiative and action aimed at strengthening the might and power of the Polish State; h) establishing and maintaining contacts with Poles abroad; i) spreading the cult of the greatness of meritorious Poles; j) propaganda of the most vital interests of the State, such as the defence of its borders, access to the sea, the development of aviation, etc.k) awakening responsibility for the good and power of Poland" (Ibid.). Cf. Regulations of the Youth Tourism Clubs, Official Journal of the Brzesko School District Board 1936, no. 2, pp. 35; L. WĘGRZYNOWICZ, Organizacja ruchu krajoznawczego młodzieży szkolnej w Polsce. Odbitka z Pierwszego Ogólnopolskiego Kongresu Krajoznawczego, Poznań 1929, pp. 1-6.

${ }^{7}$ Kola krajoznawcze młodzieży szkolnej Polskiego Towarzystwa Krajoznawczego, Ziemia 1937, no 4-5-6, pp. 130-132; Z życia organizacji krajoznawczych, Orli Lot 1920, no. 1-2, pp. 14-15; Polskie Towarzystwo Krajoznawcze Oddziat w Krakowie, Orli Lot 1920, no. 5, pp. 51. Cf. K. STASZEWSKI, Koła Krajoznawcze Młodzieży Szkolnej PTK, Ziemia 1968, no. 2, pp. 147.

${ }^{8}$ S. NIEMCÓWNA, Metodyka pracy w szkolnych kołach krajoznawczych młodzieży, Krakow 1991, pp. 1. Contemporary authors also published works concerning the value of tourism and the need for tourism education 
of work of school tourism clubs in interwar Poland. The article is based on the source research conducted using history methodologies comprising the analysis of sources, methods of establishing facts, their ordering, classification, explaining, identifying relations between them and combining them into a historiographic synthesis.

\section{An outline of the ideologies of school tourism clubs}

The methodology of work of school tourism clubs in the Second Republic of Poland was based on their ideology and the programme of the national tourism movement of schoolchildren and youth resulting from the activity of the Polish Tourism Association established in 1906, headed by Aleksander Janowski, Kazimierz Kulwieć, Zygmunt Gloger, Aleksander Patkowski and others. The tourist movement of schoolchildren and youth also had its leaders, "spiritual fathers", such as the aforementioned Leopold Węgrzynowicz, Stanisława Niemcówna, Stanisław Pawłowski, Tadeusz Seweryn, Aleksander Janowski and others.

Stanisława Niemcówna ${ }^{9}$, geographer and historian,professor of methodology of geography teaching at the Pedagogical Study of the Jagiellonian University, identified the school tourism movement primarily with getting to know and understanding the nearest surroundings. Standing in the position of regional geography at school, she wrote about living and becoming a part of the natural environment. ${ }^{10}$ For her, the environment was one of the basic factors shaping the personality of a human being, which, as she wrote, was confirmed by geopsychological research. She pointed out the importance of natural, geographic, cultural and economic environment. She wrote that for the development of the child's psyche, the basic value is to get to know their nearest environment, the nearest neighbourhood; and to take part in the tourism movement, which she considered to be the primary educational factor. According to her, living and experiencing the environment has many advantages, first of all it forms a sense of reality, because it allows for accurate observation of the landscape; it shapes the ability to compare facts; it develops the ability to name what has been ob-

(e.g. DENEK K. W kręgu edukacji, krajoznawstwa i turystyki w szkole, Poznań 2000, Eruditus; K. DENEK, Krajoznawstwo i turystyka w polskiej szkole. Tradycje - współczesność - wyzwania, [in:] O potrzebie krajoznawstwa w edukacji szkolnej, K. DENEK, L. DROŻDŻYŃSKI, A. GORDON (eds.), Warsaw - Poznań 2009 , Wydawnictwo PTTK Kraj; A. GORDON, Polskie Towarzystwo Turystyczno Krajoznawcze w kształtowaniu postaw krajoznawczych i umiejętności turystycznych dzieci i młodzieży [in:] O potrzebie krajoznawstwa w edukacji szkolnej, K. DENEK, L. DROŻDŻYŃSKI, A. GORDON (eds.) Warsaw - Poznań 2009, Wydawnictwo PTTK Kraj; D. HYŻAK, Działalność krajoznawczo-turystyczna w szkole jako nośnik wartości. Przykłady dobrej praktyki, [in:] O potrzebie krajoznawstwa w edukacji szkolnej, K. DENEK, L. DROŻDŻYŃSKI, A. GORDON (eds.), Warsaw - Poznań 2009, Wydawnictwo PTTK Kraj; Krajoznawstwo i turystyka w szkole. Poradnik, ed. A. GORDON, Warsaw 2003, Polskie Towarzystwo Turystyczno-Krajoznawcze.

${ }^{9}$ Stanistawa Niemcówna: a pioneer of Polish geography and tourism didactics. Materials from the session organised on the 15th anniversary of her death. A. JELONEK, T. GAWEL (eds.), Krakow, 1974, Instytut Geografii UJ, pp. 44.

10 S. NIEMCÓWNA, Wżywanie się w środowisko jako czynnik wychowawczy, Ruch Pedagogiczny 1932, no. 1 , pp. 13-19. 
served, to tell stories about the subject of observation; it teaches how to use drawing in a juxtaposition of various phenomena occurring in the environment; shapes the ability to explain the observed phenomena and to synthetically approach them and present them to others.

According to S. Niemcówna, becoming a part of the environment leads to a deepening of factual knowledge, allows students to compare their judgements about reality with reality itself, with the facts and phenomena occurring in it. It teaches how to answer questions such as What? When? How long? Under what conditions? Why? At the same time, it stimulates emotional attitude to the natural, social or cultural environment, builds emotional connection with it, awakens sensitivity to the beauty of the surrounding world, beauty of the landscape and shapes character, helping to overcome internal resistance, laziness, and indecision. Sightseeing trips, thanks to which young people got to know their immediate and remote surroundings, developed a fortitude and strengthened the will which is indispensable in all parts of the educational process. They taught decision-making, self-control, concentration, discussion and silence. By getting to know the natural environment, becoming familiar with it, young people have the opportunity to discover themselves and "see human in another human being." 11 S. Niemcówna was of the opinion that becoming a part of the environment of a home country shaped attitudes towards one's homeland and the state, developed patriotism and became an element of civic education.

Stanisław Pawłowski, professor at the University of Poznań, presented assumptions of tourism in the area of education that were similar to those presented by S. Niemcówna, formulating its objectives and tasks. He conflated tourism movement in schools with geography and proposed the use of geographical methods. ${ }^{12} \mathrm{He}$ supported the necessity of maintaining a balance and harmony between the different departments in tourism work, which meant that some phenomena could not be overlooked at the expense of others. He pointed out the need for young people to be interested in both the phenomena of physical geography (observation of terrain, climate, flora, fauna, etc.) and anthropogeographic phenomena, especially economic geography, which served to develop the so-called real sense. He encouraged to combine geographical phenomena with history and wrote that the aim of any school-based tourist club should be to identify characteristic phenomena that distinguish a given area from another. ${ }^{13}$

S. Pawłowski pointed out that the objectives of the tourism work carried out in schools go beyond collecting material intended for professional scientific purposes, which young people belonging to school tourism clubs and their supervisors were persuaded to do. $\mathrm{He}$ emphasised that the scientific material is collected by specialised institutions and people prepared for this work. The overarching aim of tourism in school was to get to know one's own homeland. "Why would one burden oneself with unnecessary goals, for which the young tourist has no preparation other than a pinch of good will?"14 He held the opinion

\footnotetext{
11 Ibidem, p. 18.

12 S. PAWŁOWSKI, Cele i zadania krajoznawstwa w Polsce, Orli Lot 1927, no. 2, pp. 26-29.

13 S. PAWŁOWSKI, Krajoznawstwo a geografia, Ziemia 1926, no. 23-24.

${ }^{14}$ Idem, Cele i zadania krajoznawstwa w Polsce, pp. 28.
} 
that one should not limit tourism work only to one's own country, even though its goal was to get to know one's own homeland. Because of the young people's passion for travelling, it was necessary to make it easier for them to get to know other countries through the use of books, maps and travel journals.

In terms of methodology, according to S. Pawłowski, the tourism work should have an analytical and descriptive character, as the synthetic works were too difficult for schoolchildren. The analytical works were to be based on personal experiences, on direct contact with the phenomenon described, which is why reports from tours and descriptions of geographical phenomena prepared by students were so important. According to S. Pawłowski, the tourism work should include young people aged 13 to 16 , which is why magazines devoted to tourism and addressed to young people should consider their development and publish articles that were neither too banal nor too difficult to understand. He stressed the importance of cooperation between young people in editing the journal, which included sending their own contributions and materials from excursions, observations and conversations. Photographs and drawings made by young people as well as descriptions based on personal experiences deserved special attention. ${ }^{15}$

Tadeusz Seweryn treated tourism more broadly than Stanisława Niemcówna, who was mentioned earlier. He wrote that when Poland regained its independence, the aim of the Polish tourism movement was to "Get to know in order to love". This was the motto behind the activities of the school tourism clubs. Sightseeing tours and hikes in various regions of Poland were supposed to blur the differences resulting from the partitions, lack of knowledge of particular districts and their inhabitants. In his opinion, tourism among children and youth was also a part of the new ideal of upbringing formulated in 1929 by Sławomir Czerwiński, Minister of Religious Denominations and Public Education, also referred to as a warrior-worker. Thus, it was one of the means of civic education, integrating the country and its inhabitants. ${ }^{16}$

In the school tourism movement, T. Seweryn emphasised the independence of its members, which he saw in the independent discovery of the essence of Polish life, learning about the Polish land, taking up tourist initiatives and leaving established judgements behind. In his opinion, the independence of young tourists led to the upbringing of an active citizen who respected their own state and its natural, socio-cultural, economic, ethnographic and other values. He emphasised the great social and educational value of the tourism movement. He considered it a method of "shaping a special type of human culture (...), educational moments play a crucial role in tourism, thus deepening the emotional and rational attitude of young tourists towards their homeland (...), a sense of citizenship, awakening independence in cognition and initiative in action." 17

15 Ibidem.

16 T. SEWERYN, Ideologia i metoda pracy $w$ kołach krajoznawczych młodzieży szkolnej, Ziemia 1935, year XXV, no. 9, pp. 180-183.

${ }^{17}$ Ibidem, p. 181. 
Aleksander Janowski, a pioneer of tourism and co-founder of the Polish Tourism Society, an official in the Ministry of Religious Denominations and Public Education, wrote about tourism in schools. He was delighted with the tourism work of the children from the Piaski Luterskie near Lublin, who under the leadership of the headmaster of the school, Florian Kotliński, collected rich sightseeing materials and published them in the school's magazine Nasza Szkoła. ${ }^{18}$ A. Janowski presented different views compared to S. Pawłowski. He held the opinion that Poland was waiting for a detailed sightseeing inventory to be made by students under the supervision of teachers. He called on young people and teachers to "carry out the great and important national work," which would encompass making records of interesting and important national sightseeing peculiarities by members of school tourism clubs. ${ }^{19} \mathrm{He}$ emphasised the importance of school for tourism as a lever of nation's culture, which can make children and youth and the local populace aware of the importance of tourism work, because each thorough report from students' trip is an excellent material for scientists.

At the end of these deliberations, which are short out of sheer necessity, I would like to mention Aleksander Kawałkowski's position, who wrote that if the aim of upbringing was to be a citizen working for the collective good, then the didactic and educational process based on the principle of updating should be anchored in real life, in the surrounding reality, far from tenderness, literature and abstraction. Therefore, the activities of the school should be related to tourism, which would enable students to get to know the land and the surrounding environment. Tourism, understood as a method of educational work, could be used in all areas of school and out-of-school life of children and youth, in the work of all student organisations, operating on the school grounds and outside the school, for example, in scouting. ${ }^{20}$ It is worth mentioning that the methodology of school tourism clubs was compatible with the methods of work in scouting, based on tourism, sightseeing and regionalism. ${ }^{21}$

\section{Steps in the internal development of school tourism clubs}

Stanisława Niemcówna was the creator of the methodology of the school's tourism clubs in interwar Poland. Due to their internal development, she identified three groups of these student organisations: young (newly formed) clubs; clubs undertaking independent tourism work; and advanced clubs. ${ }^{22}$

18 A. JANOWSKI, Krajoznawstwo $w$ szkole, Orli Lot 1925, no. 1, pp. 1-4. Cf. Elementy środowiskowe w nowych programach, Zrąb 1933, vol. 15, pp. 6-40.

19 Ibidem, p. 2.

${ }^{20}$ A. KAWAŁKOWSKI, Krajoznawstwo a wychowanie, Ziemia 1935, vol. XXV, no. 9, pp. 178-179.

${ }^{21}$ G. BICZYSKO, Turystyka i krajoznawstwo w Zwiąku Harcerstwa Polskiego w II Rzeczypospolitej, Prace Naukowe Akademii im. Jana Dlugosza. Series: Kultura Fizyczna, 2011, vol. X, pp. 43-55.

22 Z. KISIELEWICZ, Metodyka pracy w kołach krajoznawczych, Przegląd Krajoznawczy 1938, no. 4/5. 
S. Niemcówna believed that each tourism club should go through three stages of development. The first stage meant the assumption that the members of the newly formed tourist club did not know much about Poland, their region, their surroundings, their home town and their villages. This meant that it was necessary to start working from ground up in such a club, from getting to know the nearest surroundings, from the topographic analysis of one's own town and the closest vicinity. The idea was not only to draw up a plan, but also to get to know the nearest area in terms of geography, nature, economy, history and culture. Thanks to walking around the area, members of tourist clubs learned to observe the smallest details of its life, understand the various phenomena taking place in it, particularly geographical, economic, social, cultural, and especially natural ones. ${ }^{23}$

This first stage of the activity of the school tourism clubs was aimed at developing a willingness to tour and go on trips. As S. Niemcówna pointed out: "Being in the midst of nature is revitalising for physical and spiritual health and development. (...). The beauty of landscapes teaches us about the aesthetic element and does not allow the young tourists to destroy vegetation or litter in the mountains, instead it turns them into defenders of nature, as well as cultural monuments and human labour. ${ }^{24}$ The first stage of the work of the school clubs meant shaping the culture of tourism, the strengthening of which ensured the longevity of the school tourism club.

The second stage in the development of the activities of the school tourism clubs was based on the foundations of the tourism work carried out in the first stage and involved the acquisition of natural and historical knowledge. In this respect, the assistance was provided by school education, didactic work of teachers carrying out the curriculum of particular subjects and the activities of school self-education clubs. Thanks to this, applying the principle of difficulty grading, young tourists got acquainted first with their home town and its nearest surroundings, and then with individual regions and areas of the whole Poland. Still, the best way of working were trips preceded by lectures presenting the comprehensive issues of the visited area. ${ }^{25}$

The participants of the sightseeing tours to near and far destinations were to be prepared and equipped with maps, notebooks, an agenda and a camera. Such equipment made it easier to record observations, take photographs, collect samples, postcards and other material characteristic of a particular environment observed during the trip. Practical implementation of the tourism work made it possible to prepare a report, accompanied by illustrative material, sent to the editorial office of the Orli Lot monthly, in which it was published.

It is worth noting that since 1924 the editorial staff of Orli Lot has been supervising the school tourism clubs and cooperating closely with them. Said cooperation was based on the fact that every issue of the magazine was filled with sightseeing works of one of the school clubs. In order to give a uniform direction to the work of the school tourism

\footnotetext{
23 S. NIEMCÓWNA, Metodyka pracy w kołach krajoznawczych, Orli Lot 1921, no. 3, pp. 35-37.

${ }^{24}$ Ibidem, pp. 35-36.

25 Ibidem, p. 36.
} 
clubs, the Commission of School Youth's Tourism Clubs of the Main Board of the Polish Tourism Association published questionnaires in Orli Lot, according to which the students conducted their tourist research and collected materials which were later published in the magazine. ${ }^{26}$ "This would be a deliberate, organised work, the benefits of which would be of great importance to Polish tourism, and, most importantly, it would be work done by Polish youth." 27

The questionnaires were used to collect scientific material. The sheets were created by experts and were uniform for all clubs. After collecting the research material, the completed questionnaire had to be sent back to the experts for analysis and preparation. The questionnaires filled in by the young people were also published in Orli Lot and sent to the clubs by the Presidium of the Commission of School Youth's Tourism Clubs. It was believed that the collection of natural, geographic, historical, ethnographic and other data by children and youth in the vicinity and region according to professionally prepared questionnaires would contain scientific and educational values, because it requires reliable work and arouses interest in the issues of tourism and the closest environment. ${ }^{28}$ Each club was obliged to prepare answers to at least one questionnaire each year, announced by the Commission of School Youth's Tourism Clubs, and to implement its own programme, adequate to the local conditions and characteristics of the region where the youth lived. ${ }^{29}$

The beginning of the students' work in the school tourism clubs was connected with intellectual and technical preparation for conducting observations, taking measurements, drawings, photographs, writing descriptions and simple experiments. The technical preparation comprised providing the club as a student organisation and its members with equipment used during the trips, which included: a compass, a barometer, a measuring line, a set of detailed maps of the nearest area, a camera, binoculars and other items of equipment used during the trips. Appropriate equipment was also required in particular sections of the school tourism clubs.

It should be added that more numerous circles were divided into sections such as: vocal and artistic, dance, nature, history and culture, civic education (which presented issues related to the duties of Poles and their rights, in accordance with the Constitution) and other, which should also have their equipment. For example, the botanical section, which had its herbarium, had to purchase it, the zoological section had nets and boxes for insects, the geological section - a geological hammer, etc. ${ }^{30}$ Rudolf Hajnos wrote that during inclement weather conditions, during various seasons of the year or in the face of financial difficulties, it was not easy to organise a sightseeing trip. Therefore, he recommended buying

${ }^{26}$ Orli Lot 1929, no. 6, p. 101.

${ }^{27}$ Ed. art., O pracy w kołach krajoznawczych młodzieży, Orli Lot 1926, no. 5, p. 66.

${ }^{28}$ Organizacja Kół Krajoznawczych Młodzieży Szkolnej, [in:] Koła Krajoznawcze Młodzieży Szkolnej. Idea - Organizacja - Historia - Pieśni, Krakow 1934, Nakład Komisji Kół Krajoznawczych Młodzieży Szkolnej Rady Głównej Polskiego Towarzystwa Krajoznawczego, Krakow 1934, p. 8.

29 T. SEWERYN, Ideologia i metoda pracy $w$ kołach krajoznawczych młodzieży szkolnej, Ziemia 1935, no. 9 , p. 182.

${ }^{30}$ S. NIEMCÓWNA, Metodyka pracy w kołach krajoznawczych, Orli Lot 1921, no. 4, p. 51. 
a sciopticon (slide display) and a cinematograph. These devices were to facilitate meetings of members of school tourism clubs in the form of lectures with illustrations. ${ }^{31}$

The tourist clubs set up their own school archives, to which the young people submitted the best reports, as well as ordered samples brought back from trips. Various poems, songs, drawings, caricatures recording characteristic events from the trip, which were also of archival value, were welcomed.

The last, third stage of the work of the school tourism clubs was connected with reaching a certain level of maturity in terms of tourism. "Tourists who grow up to become independent citizens should deepen their knowledge, often specialising in a certain direction, in order to become trip guides for others. Their main task is to familiarise themselves with the folk culture of mankind and especially of their nation, particularly the matters which are absent in the school curriculum. This opens a way to researching art and ethics, to reflecting on the duties and rights that Poland imposes on us." 32 These tasks could be carried out by student councils, which at the beginning of the 1920 s were referred to as school communities. ${ }^{33}$ Another form of implementation of mature tourism in schools could be reading civic works. Reading the works of Stanisław Prus Szczepanowski, Karol Libelt, Antoni Chłoniewski, Fryderyk Wilhelm Foerster and others was encouraged. After reading these works, discussions were held at the meetings of the school tourism clubs on the issues raised in the given text, the conclusions of which could serve as examples of civic work.

Such a three-stage cycle of development of school tourism clubs, which constituted a part of the methodology of their work, led the students to "a deep understanding of the conditions of their nation's existence, the feeling of its needs and the conviction obliging them to cooperate, that everything that is Polish should never be alien to them." ${ }^{34}$

\section{Notes regarding methodology of the activities of school-tourism clubs}

The interwar period became the most important environment of the tourism work, because the curricula, mainly of elementary schools (geography, nature, history, Polish language), saturated with content related to tourism, allowed to include all the students in the educational impact. " ${ }^{35}$ "The aim of the work is to broaden and deepen the knowledge about

\footnotetext{
${ }^{31}$ R. HAJNOS, Skioptikon i kinematograf na ustugach krajoznawstwa, Orli Lot 1921, no. 11, pp. 131-133 .

32 Ibidem, p. 37.

33 D. KOŹMIAN, Samorząd uczniowski w polskiej pedagogice Drugiej Rzeczypospolitej (1918-1939), Szczecin 1991, Wydawnictwo Naukowe Uniwersytetu Szczecińskiego.

34 S. NIEMCÓWNA, Metodyka pracy $w$ kołach krajoznawczych, Orli Lot 1921, no. 3, p. 37.

${ }^{35}$ E. MAGIERA, Wychowanie państwowe w szkolnictwie powszechnym w Drugiej Rzeczypospolitej, Szczecin 2003, Wydawnictwo Naukowe Uniwersytetu Szczecińskiego, pp. 76-81.
} 
Poland, as a country and a nation," wrote S. Niemcówna. ${ }^{36}$ The guidelines formulated in this way for the tourism movement in schools were closely connected with the implementation of the curricula of elementary schools and were part of their construction, which was based, among other things, on real assumptions, understood as the school's connection with reality, which is expressed in a triple interpretation, as the principle of: teaching practical subjects, updating teaching and environmental diversity, and a broader understanding of regional diversity. ${ }^{37}$

S. Niemcówna stressed the principle of insight in the implementation of curricula, which made it possible to combine the process of education with the implementation of the idea of tourism. She considered tourism to be "the greatest treasury of insight in teaching." ${ }^{38}$ She appreciated scientific aids and saw the need for their gradual creation and application in youth work through the use of district maps, town monographs, tourist films and other didactic aids. Tourist clubs operating in elementary schools were involved in the implementation of the postulate of inter-school correspondence, which could lead to mutual visits of students, getting to know the nearest surroundings and its geographical, folkloric, economic and historical specificity. ${ }^{39}$

An important role was played by the club's teacher-supervisor, who not only had substantive knowledge in the field of tourism, but also organisational skills and methodological knowledge pertaining to conducting the tourism work. The proper operation of the school tourism clubs depended on the degree of involvement and preparation of its teachers-supervisors, whose task was to provide young people with appropriate methodological guidelines, outlining their content, methods and forms of activity. Children and youth were to be instructed not only in the methodology of sightseeing, but also in the scope and content of the activities of young tourists. The teacher could use the available literature recommended by the editorial team of Orli Lot, which printed lists of recommended books.

No less important was the preparation of the students for the tourism work, which covered all the areas of activity of school tourism clubs. The proper operation of the school tourism clubs was based on compulsory and planned preparatory work, involving the participation of young people in a compulsory cartographic course organised at the club's meetings, where the students acquired skills not only in reading maps, but also in creating their own plans and maps. Acquisition of such skills required familiarisation with relevant literature. ${ }^{40}$ Short excursions, organised only for cartographic purposes, during which they

36 S. NIEMCÓWNA, Zadania pracy krajoznawczej w Polsce, Ziemia 1931, vol. XVI, no. 4, p. 62.

${ }^{37}$ K. GREB, Jak czytać nowe programy?, Praca Szkolna 1933/34, no. 2, p. 50. Cf. W. CYRANKIEWICZ, Wiazanie pracy szkolnej ze środowiskiem w nowym programie szkoły powszechnej, Praca Szkolna 1934/35, no. 6, pp. 165-172 and 193-200; H. JĘDRUSIAK, Dziecko i społeczność szkolna w środowisku, Warsaw, nd.

38 Ibidem, p. 64.

39 F. MITTEK, Zasady organizacji pracy w szkołach powszechnych dostosowane do Statutu publicznych szkół powszechnych i nowych programów nauczania, Warsaw 1938, Nasza Księgarnia, p. 253.

${ }^{40}$ Ibidem, p. 52. Among the recommended works was a paper by Jerzy LEWAKOWSKI titled Terenoznawstwo i kartografia wojskowa. Podręcznik dla Organizacyi Wojskowych i Drużyn Skautowych, Lviv 1916, Nakład Związku Polskich Gimnastycznych Towarzystw Sokolich. 
became acquainted not only with reading and finding their position on the map, but also with the equipment, its use and application during small experiments, were of great value for the young people.

One of the mandatory skills for the members, which should be possessed by at least some students, was operating a photo camera. Photos taken during the excursions, developed in school were resold and supported the club budgets or were used to create exhibitions, collections and carry out exchanges with other clubs in Poland. It was recommended that each club should have its own meteorologist - a member who would take care of the barometer, observe and record the weather, know the weather phenomena and be able to explain them to others and try to predict the weather, as usually was the case with villagers on the basis of observable natural phenomena. ${ }^{41}$ Lucjan Orkisz pointed out the importance of knowledge of the climate. He wrote about the need for the school tourism clubs to study the components of climate, including temperature, air pressure and humidity. $\mathrm{He}$ pointed out the necessity of training in observing atmospheric phenomena, not only temporary, but also long-term ones. ${ }^{42}$

School tourism clubs were engaged in collecting plants characteristic of particular regions of the country and creating herbariums. These activities also involved preparing young people encouraging them to read the relevant subject literature, identifying plants, sketching, collecting, drying and storing them. The book Metodyka wycieczek szkolnych was recommended, since it contained an article on collecting plants. ${ }^{43}$ However, emphasis was put primarily on medicinal plants that could be collected, dried and delivered to school pharmacies or the clubs' first aid kits, as well as sold.

S. Niemcówna encouraged the members of the school's tourist clubs to pick mushrooms and eat them, by saying that they could "constitute one of the important elements of everyday nutrition." ${ }^{44}$ She also fostered the interest of the members of the clubs in observing the fauna, outside just collecting samples of the flora. The work of the young tourists was to get to know the geographical distribution of animals, their adaptations to living conditions, observing their habits and protecting the environment. An important role was played by sightseeing observations conducted among the inhabitants of the studied environment, which comprised collecting and recording folk customs and songs, as well as studying the activities of economic and cultural institutions. When taking notes on ethnographic issues, students were supposed to include description of the region, environment, general area and ethnographic description of the studied area. Methodological notes on the ethnographic surveys were published in the "Orli Lot" magazine.

Schools were encouraged to introduce sightseeing mornings, during which selected regions of the country were presented, supported by natural and historical illustrations.

41 S. NIEMCÓWNA, Metodyka pracy $w$ kołach krajoznawczych, Orli Lot 1921, no. 3, p. 37.

42 L. ORKISZ, Meteorologia jako jeden z punktów programu pracy w kołach krajoznawczych, Orli Lot 1922, no. 4, p. 77.

43 J. TRZEBIŃSKI, Florystyka, [in:] Metodyka wycieczek krajoznawczych. Wydanie drugie. Polskie Towarzystwa Krajoznawcze, Warsaw 1919, pp. 47-52.

44 Orli Lot 1921 , no. 6, p. 85. 
The meetings were enriched by the recitation of poems with tourism content, as well as folk songs that propagated Polish culture. An additional attraction were fairy tales and legends told in the local dialect, in folk clothes, which helped to get to know the folklore of the Polish land. The meetings of the school tourism clubs were animated by folk dances. All these elements of work in the school tourism clubs introduced a pleasant and cheerful atmosphere. At the same time, they attracted young people to the idea of tourism. ${ }^{45}$

The author of the methodology of school tourism clubs devoted a lot of attention to the subject of observation of young tourists, dividing it into two types: 1) physiographic observations and 2) anthropological and ethnographic observations. She also pointed out the need to visit architectural monuments and discuss issues of a political nature, such as the constitution, with experienced sightseeing experts. She also noticed the influence of young tourists on the population, which meant that when they travelled around the country, they could influence the local populace in an inclusive way and "the idea of Polish statehood would benefit from it." ${ }^{\prime 4}$

The development of the school's tourist clubs required small contributions from their members, which allowed them to purchase the necessary equipment. S Niemcówna stressed the importance of a well-run "club treasury", which not only enabled the purchase of the necessary equipment and the payment of contributions to the Polish Tourist Association and to the Orli Lot magazine, but would also constitute a kind of bank "from which poorer tourist locals could draw either financial aid or loans for trips. The club funds should be open and should support tourism projects such as the construction of a hostel, such as the Chałubiński House in Zakopane, and should support tourism publications in order to remove the tremendous burden of expenditure from the government's shoulders." 47 The payment of membership fees was considered to be an expression of conscientiousness and civic attitudes. It was stressed that this was a very important area of activity of the school tourism clubs, on which the quality of their functioning and participation in trips of less affluent students depended.

\section{Importance of sightseeing tours}

In the interwar period, longer group tours, which were prepared in a planned and well thought-out manner, played an important role in the work of schoolchildren and youth. ${ }^{48}$ Among the participants there were students - experts in various fields, prepared in advance, who during the trip informed their friends about the specifics of the visited area and

${ }^{45}$ S. NIEMCÓWNA, Metodyka pracy $w$ kołach krajoznawczych, Orli Lot 1921, no. 3, p. 36.

${ }^{46}$ M. WOŹNOWSKI, Koła Krajoznawcze Młodzieży w Polsce. Referat wygłoszony na I. Zjeździe Kót Krajoznawczych Młodzieży w Krakowie dnia 5 czerwca 1927 r., Orli Lot 1927, no. 7, p. 131.

47 S. NIEMCÓWNA, Metodyka pracy w kołach krajoznawczych, Orli Lot 1921, no. 4, pp. 50-53.

48 B. PISARSKA, W poszukiwaniu idei rozwoju turystyki. Przeszłość-przyszłość, [in:] Przeszłość, teraźniejszość i przyszłości turystyki. Warsztaty z Geografii Turyzmu, B. Krakowiak, J. Latosińka (eds.), Łódź 2014, Wydawnictwo Uniwersytetu Łódzkiego, pp. 131-144. 
thus facilitated conducting multifaceted observations. "After all, the observation material should not only reach out to our imagination superficially," wrote S. Niemcówna, "but should also be preserved and reinforced with cognitive material in order to make the trip a significant benefit." 49

An important element of the sightseeing tours was the preparation of the young people to visit the monuments. This was done through courses organised by student tourist clubs in schools, where members of the clubs learned not only about Polish monuments, but also about the method of presenting historical monuments..$^{50}$ The same procedure was followed for learning about the history of painting, music and dance. The issue of a high - "spiritual" level was highlighted at the time in school tourism clubs, which allowed for carrying out aesthetic education and familiarisation of students with aesthetic culture and its history, as well as its appreciation and respect.

School tourism clubs and, in particular, sightseeing trips developed the civic education introduced into the school curriculum, familiarising students with the life of the Polish state and its conditions, as well as the various manifestations of social, economic and cultural life. Thanks to this, young people not only broadened their intellectual horizons, but also, especially during their trips, learnt what an independent state is and what it means. It was learning based on getting to know and experiencing various areas of Polish life and deepening students' attitudes towards their homeland, on awakening and reinforcing love for the homeland and emotional involvement in one's own land. ${ }^{51}$ Thanks to sightseeing tours, students acquired various practical skills and character skills, developed a positive attitude towards the state and the homeland, and prepared for civic life.

It was stressed that the work of school tourism clubs, which should primarily take place during sightseeing tours, is not only about conducting tourism research, but also about "a broad and serious impact of young tourists, people who love Polish culture and want to elevate it, on a very low level of our folk masses in the broadest sense of the word." 52 When local people see that others value and appreciate their region, they will start to see for themselves the value of their land and their environment. S. Niemcówna believed that there was an urgent need to organise trips to the Borderlands, thanks to which their ties with Poland would be deepened and the knowledge Polish language would be reinforced. She pointed to the optimism of the young tourists as a tool for raising the level of development in the country. She wrote: "Nothing has yet been built by renouncement!"53

The methodology of school trips was contained in the book by Kazimierz Kulawieć, which after Poland regained independence helped in conducting sightseeing work with

49 Ibidem, p. 87.

${ }^{50}$ S. NIEMCÓWNA, Metodyka pracy w szkolnych kołach krajoznawczych, Orli Lot 1921, no. 7, p. 98.

51 Ibidem, p. 99.

52 S. NIEMCÓWNA, Metodyka pracy w szkolnych kołach krajoznawczych, Orli Lot 1921, no. 8-10, p. 116.

${ }^{53}$ Ibidem, p. 117; S. NIEMCÓWNA, Akcja wycieczkowa, Ziemia 1935, volume XXV, no. 9, pp. 180-183 . 
young people. ${ }^{54}$ After 1926, the importance of school trips was extended, as they were treated as a didactic and educational method, constituting a collective act. School trips, apart from their sightseeing values, took on a different meaning. They served the implementation of the sanation educational ideology and civic education. ${ }^{55}$

\section{Monitoring the work of school tourism clubs}

After four years of work carried out by the school tourism clubs and sending reports on their activities to the editorial office of the Orli Lot magazine, S. Niemcówna read them and published her comments regarding the activities of the student tourism clubs in the magazine. The analysis of the reports showed that the students' sightseeing work was characterized by far too many reports, written and delivered on the basis of the books they read, as well as stories about events and experiences from the trips. The reports contained too little information about the area visited by members of the school tourism clubs, the people living there, the landscape, culture, etc. S. Niemcówna appealed for a new direction of work in the school tourism clubs, based on the independence of the members: independent observation, independent measurements, as well as independent experiences. ${ }^{56}$ The organisers of the national tourism movement among schoolchildren were not so much interested in creating the so-called tourism literature as in getting to know their own, homeland in an independent and scientific manner. ${ }^{57}$

S. Niemcówna drew attention to one more element, which influenced the quality of work of the school tourism clubs, namely systematic, thorough and conscientious schooling, which provided the students involved in the activities of the school tourism clubs with basic general knowledge about Poland. "The school provides a method of working independently and familiarises us with the basic knowledge of natural sciences, as well as humanities, but we prefer to absorb the material presented by the teachers superficially, and when our eyes open, it is too late (...)"58 She emphasised the importance of precision, "accuracy" at work, the need to arouse interest in the surrounding world, independence, which will lead to "the deepening of students' souls and the broadening of their hearts." 59 She wrote: "At every step, in every word, seek yourself and examine whether your actions

${ }^{54}$ K. KULAWIEĆ, Organizacja wycieczek, Warsaw 1909.

${ }^{55}$ L. JAXA BYKOWSKI, Wycieczki szkolne, Lviv, 1939; A. LITWIN, Wycieczki w realizacji nowego programu. Organizacja wycieczek na podstawie nowych programów w szkole powszechnej, Warsaw 1934; B. KRYGOWSKI, Metodyka szkolnych wycieczek geograficznych, Lviv-Warsaw 1938; A. KOSIBA, Rola wycieczek geograficzno-krajoznawczych $w$ wychowaniu młodzieży $i$ wytyczne ich realizacji, Official Journal of the Lublin School District 1933, no. 5.

${ }^{56}$ S. NIEMCÓWNA, Samodzielna praca krajoznawcza młodzieży, Orli Lot 1923, no. 8, pp. 114-115.

${ }^{57}$ S. NIEMCÓWNA, Metodyka pracy w szkolnych kołach krajoznawczych, Orli Lot 1921, no. 8-10, p. 117.

\footnotetext{
${ }^{58}$ Ibidem, p. 115.

${ }^{59}$ Ibidem.
} 
correspond to the best will to serve God and the Homeland. Through such an independent work, you will not only get to know your country better and learn to study the issues of vital importance to the Polish state, but you will also spread that knowledge among the people in your surroundings. What is more, you will become conscientious, professional workers with a broad knowledge acquired thanks to the tourism culture. $"{ }^{60}$

The Orli Lot magazine played a significant role in the development and monitoring of school tourism clubs. Since the editors of the magazine began to print the works of the youth, the interest of the readers has increased, and the interest in tourism and national studies has also intensified. It was not only the editorial staff who had an insight into the activities of school tourism clubs all over Poland, resulting from the possibility of looking at the submitted reports. All the school tourism clubs had an opportunity to get acquainted with the works and reports of individual clubs, as they were published in the Orli Lot magazine. According to the regulations, every club had to subscribe to the Orli Lot magazine.

It is also worth mentioning that in the magazine the editorial team encouraged young people to carry out their sightseeing work, assuring them that this work was not about finding unusual topics for research, discovering unusual places and making exciting scientific discoveries. They wrote that it was enough to get interested in a fence, a well, a cottage, a part of the car or clothes worn by people in the vicinity. The editorial team, however, sought to standardise the tourism activities among young people by publishing and distributing the questionnaires. The idea was also to cover the whole of Poland with a network of regions explored by students. All the school tourism clubs worked on a single topic, conducting observations and other research in areas that were adjacent to each other and that could be crossed on foot by young scientists. The area was to be marked with a $50 \mathrm{~km}$ radius, which was to be systematically researched, one village at a time. ${ }^{61}$

The support and monitoring of the school tourism clubs was carried out by the Polish Tourism Association, which in the interwar period put the emphasis on grassroots work with youth in order to prepare the future staff for the tourism sector. ${ }^{62}$ Therefore, the organisation tried to use all its influence to obtain railway discounts for schoolchildren and youth, cheap accommodation and support the school tourism conventions. ${ }^{63}$

\section{Conclusions}

The founders of the tourism movement in schools in interwar Poland were guided by the slogan underlying all the activities of these organisations - "Get to know in order to love." After regaining independence, shaping attitudes based on love for one's homeland

\footnotetext{
60 Ibidem.

${ }^{61}$ Ed. art., O pracy w kołach krajoznawczych młodzieży, Orli Lot 1926, no. 5, p. 66.

${ }^{62}$ J. GAJ, Zarys historii turystyki w Polsce w XIX i XX wieku, Poznań 2001, p. 16.

${ }^{63}$ Ed. art., O pracy w kołach krajoznawczych młodzieży, p. 67.
} 
and arousing cognitive interest in one's own country promoted integration of Polish lands and their inhabitants. Tourism clubs, which functioned alongside education, promoted not only their own ideology, but also of the ideology of civic education, and state education, the latter after the May Coup d'État in 1926. They shaped patriotic attitudes and brought up independent, creative and active citizens of the state. In pursuit of the main goal, which was to get to know the nearest area, region and country, they aimed at reducing prejudices, as well as regional and ethnic stereotypes related to the place of living in urban and rural areas. They taught respect for students" "little homeland" and its inhabitants, for the cultures of other regions, and above all, for folk culture. As Danuta Koźmian wrote: "The tourism movement in Poland has grown out of an understanding of its special educational values. ${ }^{964}$

The School Tourism Clubs, functioning under the supervision of the Polish Tourism Society, accepted and recommended by the central and local educational authorities, have clearly marked their place among many organisations operating in the area of Polish education in the interwar period. They developed a special methodology of sightseeing work, which was characterised by a wide variety of student activities, as well as original methodologies of didactic, educational and organisational work. It was part of the pedagogy of the new upbringing and the idea of John Dewey's school of work, of learning in practice, which stemmed from the philosophy of pragmatism and instrumentalism.

The members of the tourism movement in schools were involved in various independent initiatives, based on psychological and pedagogical foundations, adapted to the development phases of children and youth, aimed at getting to know their immediate surroundings, region and country. The students prepared and organised excursions, courses, camps, lectures, talks, exhibitions and competitions. They took part in sightseeing conventions, used tourist hostels, read tourist press and, most of all, conducted their own observations, collected and prepared various sightseeing materials, including geographical, natural, ethnographic, economic and other samples, which were collected in archives and museums of school tourism clubs and published in the Orli Lot magazine. Both the schoolchildren belonging to the tourist clubs and their supervisors were characterised by great involvement and full dedication to the idea of sightseeing and regionalism, and thus to the homeland and the state.

\section{Works cited}

Sources

Orli Lot 1921, no. 6.

Art. ed., O pracy w kołach krajoznawczych młodzieży, Orli Lot 1926, no. 5.

CYRANKIEWICZ W., Wiazanie pracy szkolnej ze środowiskiem w nowym programie szkoty powszechnej, Praca Szkolna 1934/35, no. 6.

${ }^{64}$ D. KOŹMIAN, Poglądy społeczno-pedagogiczne Aleksandra Kazimierza Patkowskiego (1890-1942), Szczecin 1994, Wydawnictwo Naukowe Uniwersytetu Szczecińskiego, p. 81. 
Elementy środowiskowe w nowych programach, Zrąb 1933, vol. 15.

GREB K., Jak czytać nowe programy?, Praca Szkolna 1933/34, no. 2.

HAJNOS R., Skioptikon i kinematograf na ushugach krajoznawstwa, Orli Lot 1921, no. 11.

JANOWSKI A., Krajoznawstwo w szkole, Orli Lot 1925, no. 1.

JAXA BYKOWSKI L., Wycieczki szkolne, Lviv, 1939.

JĘDRUSIAK H., Dziecko i społeczność szkolna w środowisku, Warsaw, nd.

KAWAŁKOWSKI A., Krajoznawstwo a wychowanie, Ziemia 1935, vol. XXV, no. 9.

KISIELEWICZ Z., Metodyka pracy $w$ kołach krajoznawczych, Przegląd Krajoznawczy 1938, no. $4 / 5$.

KOSIBA A., Rola wycieczek geograficzno-krajoznawczych w wychowaniu młodzieży i wytyczne ich realizacji, Official Journal of the Lublin School District, 1933, no. 5.

KRYGOWSKI B., Metodyka szkolnych wycieczek geograficznych, Lviv-Warsaw 1938.

KULAWIEĆ K., Organizacja wycieczek, Warsaw 1909.

LEWAKOWSKI J., Terenoznawstwo i kartografia wojskowa. Podręcznik dla Organizacyi Wojskowych i Drużyn Skautowych, Lviv, 1916, Nakład Związku Polskich Gimnastycznych Towarzystw Sokolich.

LITWIN A., Wycieczki w realizacji nowego programu. Organizacja wycieczek na podstawie nowych programów w szkole powszechnej, Warsaw 1934.

MITTEK F., Zasady organizacji pracy w szkołach powszechnych dostosowane do Statutu publicznych szkót powszechnych i nowych programów nauczania, Warsaw 1938, Nasza Księgarnia.

NIEMCÓWNA S., Metodyka pracy w kołach krajoznawczych, Orli Lot 1921, no. 4.

NIEMCÓWNA S., Metodyka pracy w kołach krajoznawczych, Orli Lot 1921, no. 3.

NIEMCÓWNA S., Metodyka pracy w szkolnych kołach krajoznawczych, Orli Lot 1921, no. 7.

NIEMCÓWNA S., Metodyka pracy w szkolnych kołach krajoznawczych, Orli Lot 1921, no. 8-10.

NIEMCÓWNA S., Zadania pracy krajoznawczej w Polsce, Ziemia 1931, vol. XVI, no. 4.

Memorandum of the Ministry of RDaPE (no. 66) of 8 July 1937 on tourism movement, Official Journal of the MRDaPE 1937, no. 8.

Memorandum of the Ministry of RDaPE of 22 October 1935 on School Youth Tourism Clubs; Official Journal of the Brzesko School District, 1936, no. 2.

Organizacja Kót Krajoznawczych Młodzieży Szkolnej, [in:] Koła Krajoznawcze Młodzieży Szkolnej. Idea - Organizacja - Historia - Pieśni, Krakow 1934, Nakład Komisji Kół Krajoznawczych Młodzieży Szkolnej Rady Głównej Polskiego Towarzystwa Krajoznawczego, Kraków 1934.

ORKISZ L., Meteorologia jako jeden z punktów programu pracy w kołach krajoznawczych, Orli Lot 1922, no. 4.

PAWŁOWSKI S., Cele i zadania krajoznawstwa w Polsce, Orli Lot 1927, no. 2.

Polskie Towarzystwo Krajoznawcze Oddziat w Krakowie, Orli Lot 1920, no. 5.

SEWERYN T., Ideologia i metoda pracy $w$ kołach krajoznawczych młodzieży szkolnej, Ziemia 1935, vol. XXV, no. 9.

SKOPOWSKI Cz., Koła Krajoznawcze Młodzieży Szkolnej, Przyjaciel Szkoły 1933, no. 10.

SKOPOWSKI Cz., Rys historii i pracy Kót Krajoznawczych Młodzieży Szkolnej, [in:] Koła Krajoznawcze Młodzieży Szkolnej. Idea - Organizacja - Historia - Pieśni, Krakow 1934, Nakład Komisji Kół Krajoznawczych Młodzieży Szkolnej Rady Głównej Polskiego Towarzystwa Krajoznawczego.

TRZEBIŃSKI J., Florystyka [in:] Metodyka wycieczek krajoznawczych. Wydanie drugie, Warsaw 1919, Polskie Towarzystwa Krajoznawcze.

WOŹNOWSKI M., Koła Krajoznawcze Młodzieży w Polsce. Referat wygłoszony na I. Zjeździe Kół Krajoznawczych Młodzieży w Krakowie dnia 5 czerwca 1927 r., Orli Lot 1927, no. 7.

Z życia organizacji krajoznawczych, Orli Lot 1920, no. 1-2. 


\section{Compilations}

BICZYSKO G., Turystyka i krajoznawstwo w Związu Harcerstwa Polskiego w II Rzeczypospolitej, Prace Naukowe Akademii im. Jana Dlugosza. Series: Kultura Fizyczna, 2011, vol. X

CZARNOWSKI A., Leopold Wegrzynowicz, organizator krajoznawstwa wśród młodzieży, Warsaw 1987, Wydawnictwo PTTK.

DENEK K., Krajoznawstwo i turystyka w polskiej szkole. Tradycje-wspótczesność-wyzwania [in:] O potrzebie krajoznawstwa w edukacji szkolnej, DENEK K., DROŻDŻYŃSKI L., GORDON A., (eds.) Warsaw - Poznań 2009, Wydawnictwo PTTK Kraj.

DENEK K., W kręgu edukacji, krajoznawstwa i turystyki w szkole, Poznań 2000, Eruditus.

GAJ J., Zarys historii turystyki w Polsce w XIX i XX wieku, Poznań 2001, Wydawnictwo Akademia Wychowania Fizycznego.

GORDON A., Polskie Towarzystwo Turystyczno Krajoznawcze w kształtowaniu postaw krajoznawczych i umiejętności turystycznych dzieci i młodzieży [in:] O potrzebie krajoznawstwa $w$ edukacji szkolnej, DENEK K., DROŻDŻYŃSKI L., GORDON A., (eds.) Warsaw - Poznań 2009, Wydawnictwo PTTK Kraj.

HYŻAK D., Działalność krajoznawczo turystyczna w szkole jako nośnik wartości. Przykłady dobrej praktyki [in:] O potrzebie krajoznawstwa w edukacji szkolnej, DENEK K., DROŻDŻYŃSKI L., GORDON A., (eds.) Warsaw - Poznań 2009, Wydawnictwo PTTK Kraj.

KITOWSKA M., Orli Lot (1920-1939). Z problematyki turystyczno-krajoznawczej edukacji młodzieży szkolnej [in:] Młody czytelnik w świecie ksiązki, biblioteki i informacji, HESKA-KWAŚNIEWICZ K., SOCHA I. (eds.), Katowice 1996, Wydawnictwo Naukowe Uniwersytetu Śląskiego.

KOŹMIAN D., Poglady spoteczno-pedagogiczne Aleksandra Kazimierza Patkowskiego (1890-1942), Szczecin 1994, Wydawnictwo Naukowe Uniwersytetu Szczecińskiego.

KOŹMIAN D., Samorząd uczniowski w polskiej pedagogice Drugiej Rzeczypospolitej (1918-1939), Szczecin 1991, Wydawnictwo Naukowe Uniwersytetu Szczecińskiego.

Krajoznawstwo i turystyka w szkole. Poradnik, ed. GORDONA., Warsaw 2003, Polskie Towarzystwo Turystyczno-Krajoznawcze.

MAGIERA E., Wychowanie państwowe w szkolnictwie powszechnym w Drugiej Rzeczypospolitej, Szczecin 2003, Wydawnictwo Naukowe Uniwersytetu Szczecińskiego.

PISARSKA B., W poszukiwaniu idei rozwoju turystyki. Przeszłość-przyszłość [in:] Przeszłość, teraźniejszość i przyszłości turystyki. Warsztaty z Geografii Turyzmu, vol. V, KRAKOWIAK B., LATOSIŃKA J. (eds.), Łódź 2014, Wydawnictwo Uniwersytetu Łódzkiego.

Stanisława Niemcówna: a pioneer of Polish geography and tourism didactics. Materials from the session organised on the 15th anniversary of her death., JELONEK A., GAWEL T. (eds.), Kraków, 1974, Instytut Geografii UJ.

STASZEWSKI K., Koła Krajoznawcze Młodzieży Szkolnej PTK, Ziemia 1968, no. 2. 